\title{
Indicator Analysis of the Economic Development of Polish Regions in the Context of the Implementation of the Concept of Sustainable Development
}

\author{
Anetta Barska ${ }^{1}$ and Janina Jędrzejczak-Gas ${ }^{2}$
}

\begin{abstract}
The aim of the article is to present the regional differentiation of indicators characterizing the economic development of Polish regions in the context of the progress made in the implementation of the concept of sustainable development in 2010 and 2017. The authors focused primarily on determining the position of Lubuskie Province on the economic map of Poland. The article proposes a set of indicators monitoring one of the areas of sustainable development - economic development, which also take into account other areas of sustainable development, i.e. social development, environmental development, and institutional-political development. The main criterion for the selection of indicators were substantive premises and their completeness and accessibility across the regions. The analysis and evaluation of the proposed indicators (explanatory variables) were conducted within five thematic areas which mark the economic development of the regions and which are important from the standpoint of the sustainable development concept: 1) Potential of the economy 2) Innovativeness of the economy 3) Economic activity of enterprises, 4) Production and transportation, 5) Economic activity of households. The article consists of two sections. In the first section, based on literature review, the most important issues regarding the concept of sustainable development and the state of scientific research on the indicators of sustainable development at regional level are presented. The second section addresses the concept of indicator analysis on the basis of which an assessment of economic development of 16 Polish regions was carried out and the position of Lubuskie Province was determined against the backdrop of the other regions. The findings prompted an answer to the question concerning the economic development of Polish regions, and in particular of Lubuskie Province, in the context of the concept of sustainable development.
\end{abstract}

Keywords: indicator analysis, region, sustainable development, economic development, Poland

\section{Introduction}

The presented article is the result of research on the assessment of the progress in the implementation of the concept of sustainable development in 2017, in which the year 2010 was adopted as a reference point. The study covered all 16 Polish regions, administratively referred to as voivodships (provinces), albeit attention was mainly focused on Lubuskie region. This is because the preparation of the publication counted with financial support from the Board of Lubuskie Province as part of the initiative "Small Grants for Public Universities". Additionally, the authors participated in numerous expert teams preparing strategic documents for local government units that are part of Lubuskie region. This included, among others, participation in the project no. PL 06-05 "Socio-economic development of the Odra-River Communes" co-financed from the Financial Mechanism of the European Economic Area 2009-2014 as part of the program "Urban development through strengthening the competence of local 
government units, social dialogue and cooperation with representatives of civil society".

Lubuskie region is situated in western Poland, being one of the smaller and younger Polish provinces. It was created in 1999 as a result of administrative reform, covering today most of the territories of the former Gorzów and Zielona Góra regions. Due to its relatively young age as an independent administrative unit, the level of economic development and its stimulation in Lubuskie region needs to be monitored on an ongoing basis.

The concept of sustainable development combines spatial, economic and social planning, allowing for better coordination of activities and their increased effectiveness. Due to the scope of interests and the paper's limited framework, only economic development was investigated. Given the complexity and versatility of the research, findings from the analysis and assessment of the implementation of the concept of sustainable development in Polish regions in terms of the level of economic development are presented in two separate studies constituting a coherent whole. The first one is entitled Indicator analysis of the economic development of Polish regions in the context of the implementation of the concept of sustainable development, and the second - Assessment of the development of economic development - taxonomic analysis (Jędrzejczak-Gas and Barska 2019).

The aim of this study is to outline the regional diversification of indicators marking the economic development of Polish regions in the context of the progress in the implementation of the concept of sustainable development in 2010 and 2017. Results of the analysis may help provide a better outlook on the effects of the current development policy pursued by Polish regions, including in particular Lubuskie region, and of the directions of development strategies for individual regions, including the concept of sustainable development. The article consists of two parts. In the first part, which is based on the literature, the main issues concerning the concept of sustainable development are tackled. The second part introduces the concept of indicator analysis on the basis of which an assessment of the economic development of 16 Polish regions was carried out and the position of Lubuskie region against the others was determined.

\section{The Concept of Sustainable Development - A Literature Review}

The idea of sustainable development emerged when attention was first paid to the fast and unrestrained rate of population growth, with uncontrolled exploitation of natural resources, increasing environmental degradation, and an uncontainable increase in consumption. In addition, an area of concern became the ever-expanding disproportions between highly developed and developing countries in terms of the quality of life of their residents (Brzoska and Lewandowska 2013). The idea of sustainable development thus arose in response to the growing awareness of society as to the emerging threats triggered bysteady economic growth and limited natural resources. The very term sustainable development is not uniformly defined, having appeared in 1987 in the Gro Harlem Brundtland Report by the World Commission on Environment and Development. In there, a development is defined "that meets the needs of the present generation without diminishing the chances of future generations to meet their own needs" (Brutland 1987). The Brundtland report called for the economy and nature to be understood as integrated system components, and for economic and environmental 
goals to be linked with social goals. The concept of sustainable development assumes a change in the current way of thinking and involves incorporating the natural environment into the socio-economic development of a region, a country or the world, without affect the current level of civilization development (Skowroński 2006). It should be noted that economic growth, social progress and environmental order are considered to be interdependent phenomena, which implies the necessity of joint problem-solving on the path towards sustainable development (Matuszczak 2013). However, as indicated by Poczta-Wajda and Sapa (2017), the key elements of the first two are economic freedom and the freedom to make decisions in different areas of life. Imposing specific behaviors on business entities in the context of sustainable development, or introducing restrictions and artificial regulations, undermines that freedom, and in doing so, negatively affects social development and economic growth. Furthermore, discussion on the underlying causes of the problems faced by the world today indicates that the majority of them are a direct or indirect byproduct of economic growth, the same economic growth which is also the goal of sustainable development.

Sustainable development is one of the main priorities of the Europe 2020 Strategy, a novel and long-term socio-economic program of the European Union. There are many strategic documents in Poland referring to the concept of sustainable development. The main goals, challenges and directions of the socio-economic development of the country, including the principle of sustainable development, are in fact laid out in Poland's own 2020 National Development Strategy (M.P. 2012 item 882) and in Dlugookresowa Strategia Rozwoju Kraju. Polska 2030. Trzecia Fala Nowoczesności (The Long-Term National Development Strategy. Poland 2030. Third Wave of Modernity) (M.P. 2013, item 121). The policy focuses on the following elements: innovativeness and efficiency of the economy, development of human capital, development of transportation, energy security and environmental security, efficient state, development of social capital, regional development, sustainable development of rural areas, agriculture and fisheries, and development of the national security system of the Republic of Poland (Ladysz, 2015, pp. 51-65). These strategies combine spatial, economic and social planning, allowing for better coordination of activities and their increased effectiveness. Sustainable development is a multidimensional phenomenon, and its assessment is not easy and cannot be measured and expressed by one characteristic (Cieślak et al. 2019; Raszkowski and Bartniczak 2018; Laurencio Calas and Fuentes Sardinas 2017).

\section{Methods}

The concept of economic development is not easy to define. It is worth noting that economic growth is a process of creating and enlarging the real size of a social product. This means increasing the production of goods and services made in a given country and at a given time. Development in the territorial sense goes beyond growth, as growth is understood to refer strictly to quantitative change while development encompasses both quantitative and qualitative changes. In addition to structural changes, development also includes changes in institutions and economic relations that accompany these phenomena (Pajak et al. 2016). Therefore, a number of explanatory indicators is required in order to properly characterize development (Bal-Domańska 2016; Roszkowska 
and Filipowicz-Chomko, 2016; Borys, 2003). Regional development should be based on optimal expansion constituents (social, natural and economic development aspects) aimed at certain life's level maintenance and quality improvement. He encompasses not only traditional policy on a concrete territory, but also socioeconomic process organized in the specific political and cultural context (Jovovic et al. 2017).

The article evaluates regional variation in the value of variables explaining economic development in Poland in the context of the implementation of the concept of sustainable development, broken down into thematic areas such as: 1) Potential of the economy, 2) Innovativeness of the economy, 3) Economic activity of enterprises, 4) Production and transportation, 5) Economic activity of households. Selected indicators which best illustrate economic development and the idea of sustainable development at regional level were assigned to the thematic areas (Table 1). The analysis covers all 16 Polish regions, namely: Mazowieckie, Lubuskie, Lubelskie, Śląskie, Dolnośląskie, Małopolskie, Zachodniopomorskie, Świętokrzyskie, Podlaskie, Lódzkie, Podkarpackie, Pomorskie, Opolskie, Warmińsko-mazurskie, Kujawsko-pomorskie, and Wielkopolskie. The presented data reflected the situation of the individual regions of Poland in 2010 and 2017. Explanatory variables were selected on the basis of substantive, statistical and formal criteria (primarily significance, completeness and accessibility of data for the regions in 2010 and 2017). The following statistical measures were also used: the maximum value, the minimum value, the arithmetic mean, and the coefficient of variation.

Table 1. Variable characteristics

\begin{tabular}{|c|c|c|}
\hline Area & $\begin{array}{l}\text { Descriptive } \\
\text { variable index }\end{array}$ & Variable characteristics \\
\hline \multirow{6}{*}{ 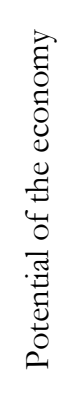 } & $\mathrm{X} 1$ & GDP per capita (current prices, Poland $=100)$ \\
\hline & $\mathrm{X} 2$ & Investment outlays per capita (current prices, Poland $=100$ ) \\
\hline & $\mathrm{X} 3$ & $\begin{array}{l}\text { Investment rate for environmental protection and water } \\
\text { management (expenditure on fixed assets for environmental } \\
\text { protection and water management relative to GDP) }(\%)\end{array}$ \\
\hline & $\mathrm{X} 4$ & $\begin{array}{l}\text { Water absorption of the economy (consumption of water for needs } \\
\text { of the national economy and population relative to GDP value) } \\
\text { (dam3 / PLN '000) }\end{array}$ \\
\hline & $\mathrm{X} 5$ & Energy intensity of transportation relative to GDP (Poland $=100)$ \\
\hline & $\mathrm{X} 6$ & Energy intensity of industry relative to GDP $($ Poland $=100)$ \\
\hline \multirow{7}{*}{ 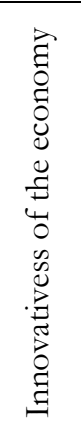 } & $\mathrm{X} 7$ & Share of innovative enterprises in the total number of enterprises $(\%)$ \\
\hline & $\mathrm{X} 8$ & $\begin{array}{l}\text { Share of enterprises from the industrial sector that incurred outlays } \\
\text { on innovative activity in the total number of enterprises }(\%)\end{array}$ \\
\hline & $\mathrm{X} 9$ & Share of R\&D employees in the economically active population $(\%)$ \\
\hline & $\mathrm{X} 10$ & $\begin{array}{l}\text { Number of inventions reported to the Patent Office of the } \\
\text { Republic of Poland per } 1,000,000 \text { residents }\end{array}$ \\
\hline & $\mathrm{X} 11$ & R\&D outlays relative to GDP (current prices, $\%$ ) \\
\hline & $\mathrm{X} 12$ & $\begin{array}{l}\text { Share of sold production of new/significantly improved products in } \\
\text { industrial enterprises in the value of sales of products in total }\end{array}$ \\
\hline & $\mathrm{X} 13$ & $\begin{array}{l}\begin{array}{l}\text { Expenditure on innovative activity in enterprises per one } \\
\text { economically active person }\end{array} \\
\end{array}$ \\
\hline
\end{tabular}




\begin{tabular}{|c|c|c|}
\hline \multirow{5}{*}{ 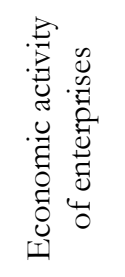 } & $\mathrm{X} 14$ & Number of business entities per 1,000 working-age population \\
\hline & $\mathrm{X} 15$ & $\begin{array}{l}\text { Number of newly registered entities per } 10,000 \text { working-age } \\
\text { population }\end{array}$ \\
\hline & $\mathrm{X} 16$ & Share of de-registered entities in the total number of entities $(\%)$ \\
\hline & $\mathrm{X} 17$ & $\begin{array}{l}\text { Share of newly registered creative-sector entities in the number of } \\
\text { newly registered entities }(\%)\end{array}$ \\
\hline & $\mathrm{X} 18$ & Investment outlays of enterprises per enterprise (Poland $=100)$ \\
\hline \multirow{6}{*}{ 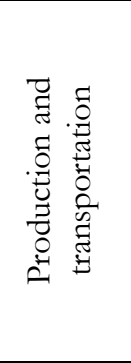 } & $\mathrm{X} 19$ & $\begin{array}{l}\text { Water consumption for the needs of industry relative to the number } \\
\text { of industrial enterprises }\end{array}$ \\
\hline & $\mathrm{X} 20$ & Share of renewable energy in total electricity production $(\%)$ \\
\hline & $\mathrm{X} 21$ & $\begin{array}{l}\text { Emission of air pollutants from particularly burdensome plants per } \\
1 \mathrm{~km} 2 \text { area }(\mathrm{t} / \mathrm{a})\end{array}$ \\
\hline & $\mathrm{X} 22$ & Share of organic farms in the total number of farms $(\%)$ \\
\hline & $\mathrm{X} 23$ & $\begin{array}{l}\text { Share of agricultural land used by organic farms in the total } \\
\text { agricultural area }\end{array}$ \\
\hline & $\mathrm{X} 24$ & Number of passenger transportmeans per urban dweller \\
\hline \multirow{5}{*}{ 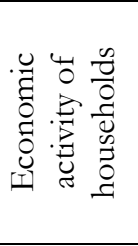 } & $\mathrm{X} 25$ & Coefficient of economic activity \\
\hline & $\mathrm{X} 26$ & Secondary-school graduates per 10,000 population \\
\hline & $\mathrm{X} 27$ & $\begin{array}{l}\text { Index of average monthly disposable income per capita in } \\
\text { households (Poland 100) }\end{array}$ \\
\hline & $\mathrm{X} 28$ & Non-working age population per 100 working-age population \\
\hline & $\mathrm{X} 29$ & Unemployment rate $(\%)$ \\
\hline
\end{tabular}

Source: own study

\section{Results and Discussion}

Monitoring of the implementation of the directions of activities in regions acting in accordance with the principle of sustainable development and taking into account social, economic and ecological cohesion is carried out by means of a carefully selected set of individual indicators (Roszkowska and Filipowicz-Chomko 2016; Wyrwa 2019; Ulfik and Nowak 2014). The proposed indicators of monitoring economic development enable the creation of a statistical map of Polish regions from the point of view of the implementation of a new paradigm of sustainable development. The first group of indicators expressing economic development are those reflecting potential of the economy and they are shown in Table 1.

An important variable is the value of gross domestic product per capita in a region expressed in Polish zlotys (PLN) in relation to the average for Poland set at 100 (Poland $=100)$, as well as related variables. If the value in question is below 100, the level of GDP per capita in a region is lower than the average for Poland, and vice versa. GDP per capita is an important indicator of the level of economic development, and its longterm increase is the main goal of a state's economic policy. Its diversified size indicates disparities in the standard of living between regions as well as differences in the purchasing power of a region's residents against others. Reducing these gaps in economic development and in the standard of living is one of the main objectives of sustainable development. In 2017, a decrease in the average value of this indicator was reported in Lubuskie region. 
In what concerns all variables in 2017, the volatility index increased compared to 2010, which signals growing disproportions between the analyzed regions of Poland. The largest variation among the regions was recorded in relation to the water-consumption index (X4), while the lowest - in investment outlays per capita. Reducing water consumption is indispensable for sustainable development. An important indicator of economic development are investment outlays geared towards creating new fixed assets as well as improving existing fixed assets, which is why they are usually a decisive factor of economic growth.

Lubuskie region scored above the average in 2010 for investment outlays per capita (current prices, Poland $=100$ ) and for energy intensity of transportation relative to GDP (Poland $=100)$. However, these rates dropped markedly below the average in 2017, which was a positive sign in relation to energy intensity of transportation relative to GDP. There is a clear improvement in 2017 against 2010 in terms of energy and transportation intensity indicators. Importantly, the transportation energy intensity indicator can be used to assess the relationship between energy consumption in transportation and economic growth. An increase in gross domestic product should not spring from an increase in energy consumption in transportation. Favorable changes in Lubuskie region in 2017 against 2010 were also observed in the scope of reducing energy intensity and water consumption of the economy, which is the expression of the implementation of sustainable development postulates (Table 2). Adequate access to water is crucial not only for the quality of life, but also for stable economic development. From an economic point of view, it is important to reduce the water and energy intensity of production processes as well as those related to municipal needs. The rational use of water and energy resources should enable satisfying the needs of both the population and the economy along with ecosystems.

Table 2. Descriptive characteristics of variables explaining the potential of the economy as an important determinant of economic development for Polish regions in 2010 and 2017

\begin{tabular}{|c|c|c|c|c|c|c|}
\hline \multirow{2}{*}{$\begin{array}{c}\text { Variables } \\
\text { reflecting } \\
\text { economic } \\
\text { potential }\end{array}$} & Year & Min & Max & Lubuskie & Mean & $\begin{array}{l}\text { Coefficient } \\
\text { of variation }\end{array}$ \\
\cline { 3 - 7 } & & & & & & \\
\hline \multirow{2}{*}{ X1 } & 2010 & 69 (Lubelskie) & 159 (Mazowieckie) & 84,5 & 91,03 & 24,74 \\
\cline { 2 - 7 } & 2017 & 68,90 (Lubelskie) & 160,40 (Mazowieckie) & 82,7 & 90,22 & 25,89 \\
\hline \multirow{2}{*}{ X2 } & 2010 & 67,30 (Lubelskie) & 146,10 (Mazowieckie) & 129,9 & 95,15 & 21,07 \\
\cline { 2 - 7 } & 2017 & 57,90 (Świętokrzyskie) & 160,90 (Mazowieckie) & 80,8 & 91,35 & 27,99 \\
\hline \multirow{2}{*}{ X3 } & 2010 & 0,59 (Zachodniopomorskie) & 2,35 (Mazowieckie) & 1,14 & 1,20 & 36,09 \\
\cline { 2 - 7 } & 2017 & 0,25 (Mazowieckie) & 1,01 (Zachodniopomorskie) & 0,48 & 0,49 & 39,17 \\
\hline \multirow{2}{*}{ X4 } & 2010 & 2,15 (Świętokrzyskie) & 37,23 (Śląskie) & 2,76 & 8,04 & 127,21 \\
\cline { 2 - 7 } & 2017 & 30,39 (Świętokrzyskie) & 1,56 (Śląskie) & 1,85 & 5,71 & 135,50 \\
\hline \multirow{2}{*}{ X5 } & 2010 & 55,6 (Podlaskie) & 195,74 (Lódzkie) & 113,08 & 106,32 & 35,95 \\
\cline { 2 - 7 } & 2017 & 38,96 (Podkarpackie) & 174,11 (Pomorskie) & 76,81 & 97,91 & 38,40 \\
\hline \multirow{2}{*}{ X6 } & 2010 & 64,82 (Lódzkie) & 216,83 (Opolskie) & 137,33 & 111,97 & 40,27 \\
\cline { 2 - 7 } & 2017 & 45,11 (Mazowieckie) & 211,31 (Świętokrzyskie) & 110,94 & 110,91 & 41,84 \\
\hline
\end{tabular}

Source: own study based on local bank data, available at https:// bdl.stat.gov.pl/BDL/start (retrieved 16.06.2019)

Another area considered significant in determining economic development is 
innovativeness of the economy, which was characterized using seven different indicators (Table 1).

Innovativeness plays a fundamental role in strengthening market position and competitive fight for products and services both domestically and internationally. The saturation of the economy with innovative products (high-tech solutions) increases its competitiveness, providing a solid springboard for sustainable development.

An important indicator reflecting innovativeness of the economy is the share of innovative enterprises in the total number of enterprises (X7). In this respect, the growing diversification of regions and a decrease in value of this indicator for Lubuskie region can be observed. However, it was rather a country-wide trend that was behind this improvement of Lubuskie compared to other regions (ranked 13 th out of 16 in 2010, and $10^{\text {thin }}$ 2017). The development of a modern, innovative economy requires the use of creativity and research potential by devising new solutions and technologies to meet objectives such as improving the quality of life while protecting natural resources. New solutions are a prerequisite for sustainable economic development, which can be expressed by an increased number employees in the R\&D sector (X9) and an increased number of inventions (X10). Higher values reported for these indicators show a positive correlation with expenditures on innovative activity in enterprises per economically active person (X13). A positive trend noted in 2017, as compared to 2010 , is also an over $60 \%$ decrease in the volatility index in relation to the variable representing expenditures on innovative activity in enterprises per economically active person (X13), which indicates the leveling of the disparities in individual regions. This, however, occurred among others as a result of lowering expenditures overall, which by itself is an unfavorable phenomenon. Lubskie region recorded in 2017 the largest share of enterprises in the industry sector incurring expenditures on innovation activities in enterprises overall (\%), which reflects the implementation of smart specialization strategies (Table 3).

Table 3. Descriptive characteristics of variables explaining the area of innovativeness of the economy as an important determinant of economic development for Polish regions in 2010 and 2017

\begin{tabular}{|c|c|c|c|c|c|c|}
\hline \multirow{2}{*}{$\begin{array}{c}\text { Variables } \\
\text { reflecting } \\
\text { innovativeness } \\
\text { of the } \\
\text { economy }\end{array}$} & \multirow{2}{*}{ Year } & \multicolumn{5}{|c|}{ Descriptive statistics } \\
\hline & & Min & Max & Lubuskie & Mean & $\begin{array}{c}\text { Coefficient } \\
\text { of } \\
\text { variation }\end{array}$ \\
\hline \multirow{2}{*}{$\mathrm{X} 7$} & 2010 & 11,90(Lódzkie) & 17,20(Podkarpackie) & 14,6 & 14,48 & 10,29 \\
\hline & 2017 & 9,10 (Warmińsko-mazurskie) & 16,80 (Mazowieckie) & 13 & 13,58 & 13,42 \\
\hline \multirow{2}{*}{$\mathrm{X} 8$} & 2010 & 6,19(Warmińsko-mazurskie) & 12,76 (Mazowieckie) & 8,39 & 9,53 & 20,19 \\
\hline & 2017 & 2,17 (Opolskie) & 12,22 (Lubuskie) & 12,22 & 6,87 & 42,49 \\
\hline \multirow{2}{*}{$\mathrm{X} 9$} & 2010 & 9,98 (Lódzkie) & 17,32 (Śląskie) & 11,5 & 13,82 & 12,75 \\
\hline & 2017 & 11,17 (Warmińsko-mazurskie) & 17,52 (Opolskie) & 12 & 14,49 & 12,71 \\
\hline \multirow{2}{*}{$\mathrm{X} 10$} & 2010 & 0,20 (Lubuskie) & 1,31 (Mazowieckie) & 0,20 & 0,58 & 52,34 \\
\hline & 2017 & 0,33 (Świętokrzyskie) & 2,21 (Mazowieckie) & 0,47 & 0,88 & 53,90 \\
\hline \multirow{2}{*}{$\mathrm{X} 11$} & 2010 & 27,40 (Lubuskie) & 133, (40 Mazowieckie) & 27,40 & 71,06 & 41,68 \\
\hline & 2017 & 55,10 (Warmińsko-mazurskie & 133,10 (Mazowieckie) & 59 & 93,90 & 25,30 \\
\hline \multirow{2}{*}{$\mathrm{X} 12$} & 2010 & 0,12 (Opolskie) & 1,36 (Mazowieckie) & 0,14 & 0,55 & 58,82 \\
\hline & 2017 & 0,20 (Lubelskie) & 2,16 (Małopolskie) & 0,2 & 7,90 & 38,80 \\
\hline \multirow{2}{*}{$\mathrm{X} 13$} & 2010 & 2,97 (Zachodniopomorskie) & 49,76 (Pomorskie) & 4,00 & 11,67 & 94,25 \\
\hline & 2017 & 4,32 (Warmińsko-mazurskie) & 13,61 (Małopolskie) & 4,77 & 7,90 & 38,80 \\
\hline
\end{tabular}

Source: own study based on local bank data, available at https:// bdl.stat.gov.pl/BDL/start (retrieved 16.06.2019) 
Economic activity of enterprises, characterized using five different indicators (Table 1), was considered another important area impacting economic development. An increase in economic activity of enterprises reflected in a number of indicators is a factor of economic growth.

Coefficient of variation as a measure of dispersion indicates that the smallest variation between regions in Poland relates to the share of de-registered entities in the total number of entities $(\%)$, which may signal the existence of similar conditions for the development of entrepreneurship in individual regions of Poland. Investment expenditure (X18), which influences the growth of innovation and competitiveness of an economy, is also very important. The highest value of the coefficient of variation was adopted for the variable denoting investment outlays of enterprises per enterprise (Poland $=100$ ) (X18), revealing a different rate of economic development of the individual regions and whose increase in 2017 against 2010 suggests continued growth of that disparity. This variable is unfavorable for Lubuskie region, making it rank $13^{\text {th }}$ out of 16 in 2017 (compared to $14^{\text {th }}$ in 2010). The analysis also indicates that the role of the creative industry in Lubuskie is decreasing, with the region ranking in $201715^{\text {th }}$ out of 16 (compared to 6 th in 2010) (Table 4).

Table 4. Descriptive characteristics of variables explaining the area economic activity of enterprises as an important determinant of economic development for Polish regions in 2010 and 2017

\begin{tabular}{|c|c|c|c|c|c|c|}
\hline \multirow{2}{*}{$\begin{array}{l}\text { Variables } \\
\text { reflecting } \\
\text { economic } \\
\text { activity of } \\
\text { enterprises }\end{array}$} & \multirow[b]{2}{*}{ Year } & \multicolumn{5}{|c|}{ Descrptive statistics } \\
\hline & & Min & Max & Lubuskie & Mean & $\begin{array}{c}\text { Coefficient } \\
\text { of } \\
\text { variation }\end{array}$ \\
\hline \multirow[t]{2}{*}{$\mathrm{X} 14$} & 2010 & 112,30 (Podlaskie) & 203,50 (Opolskie) & 119,1 & 151,08 & 17,82 \\
\hline & 2017 & 128,70 (Podkarpackie) & 250,10 (Mazowieckie) & 180 & 173,55 & 19,70 \\
\hline \multirow[t]{2}{*}{$\mathrm{X} 15$} & 2010 & 117,00 (Podlaskie) & 198,00 (Opolskie) & 129 & 155,81 & 15,92 \\
\hline & 2017 & 104,00 (Opolskie) & 207,00 (Mazowieckie) & 153 & 145,56 & 21,22 \\
\hline \multirow{2}{*}{$\mathrm{X} 16$} & 2010 & 4,90 (Opolskie) & 8,40 (Pomorskie) & 6,1 & 6,43 & 16,62 \\
\hline & $\mid 2017$ & 5,80 (Mazowieckie) & 7,60 (Warmińsko-mazurskie) & 7,4 & 6,89 & 7,85 \\
\hline \multirow[t]{2}{*}{$\mathrm{X} 17$} & 2010 & 4,90 (Lubelskie) & 7,37 (Opolskie) & 5,93 & 5,95 & 11,49 \\
\hline & 2017 & 4,85 (Zachodniopomorskie) & 8,48 (Mazowieckie) & 4,95 & 6,44 & 14,00 \\
\hline \multirow[t]{2}{*}{$\mathrm{X} 18$} & 2010 & 62,37 (Wielkopolskie) & 142,24 (Opolskie) & 79,04 & 92,01 & 24,98 \\
\hline & 2017 & 58,36 (Świętokrzyskie) & 130,74 (Mazowieckie) & 72,98 & 91,29 & 26,28 \\
\hline
\end{tabular}

Source: own study based on local bank data, available at https:// bdl.stat.gov.pl/BDL/start (retrieved 16.06.2019)

Another crucial area affecting economic development is production and transportation, which has been characterized using six different indicators (Table 1). Given the focus of the article on showing the economic development of Polish regions in the context of the progress in the implementation of the concept of sustainable development in 2010 and 2017, the selected indicators reflecting economic development were strongly related to sustainable development. They take into account aspects such as water consumption in production, the share of renewable energy, or the development of organic farms.

The high volatility index refers to the share of organic farms in the total number of farms $(\%)$ (X22), which shows the different pro-environmental orientation of the regions. 
Lubuskie in this respect is well above the national average. In the overall ranking for this indicator, it ranked $3^{\text {rdin }} 2017$ and similarly in 2010. The organic farm model, as part of the concept of sustainable agriculture, assumes the friendliness for the natural environment and the production of agricultural products with high nutritional values through the use of ecological production methods. Currently, organic farming in Poland receives financial support from the national budget and the EU budget.

Also important for economic development in the context of sustainable development is the share of renewable energy in total electricity production (\%) (X20) (Table 5). Renewable energy sources (RES) are self-regenerating and are generally considered environmentally friendly as a result of low greenhouse gas emissions and air pollution. This indicator informs about the degree of use of energy from RES in the final consumption of energy in Poland, enabling monitoring of the effects of pursued measures to promote production and consumption of renewable energy across all sectors. The legitimacy of using this indicator springs from the challenges facing Poland in reducing energy intensity of the country's economy in the medium and long term.

Table 5. Descriptive characteristics of variables explaining the area of production and transportation as an important determinant of economic development for Polish regions in 2010 and 2017

\begin{tabular}{|c|c|c|c|c|c|c|}
\hline \multirow[b]{2}{*}{$\begin{array}{l}\text { Variables } \\
\text { reflecting } \\
\text { production and } \\
\text { transportation }\end{array}$} & \multirow[b]{2}{*}{ Year } & \multicolumn{5}{|c|}{ Descriptive statistics } \\
\hline & & Min & $\operatorname{Max}$ & Lubuskie & Mean & $\begin{array}{c}\text { Coefficient } \\
\text { of } \\
\text { variation }\end{array}$ \\
\hline \multirow[t]{2}{*}{ X19 } & 2010 & 1,24 (Lubuskie) & 121,65 (Świętokrzyskie) & 1,24 & 20,58 & 166,09 \\
\hline & 2017 & 1,19 (Lubuskie) & 111,38 (Świętokrzyskie & 1,19 & 17,71 & 169,29 \\
\hline \multirow{2}{*}{$\mathrm{X} 20$} & 2010 & 0,80 (Lubelskie) & 59,00 (Kujawsko-Pomorskie) & 8,6 & 14,81 & 112,27 \\
\hline & \begin{tabular}{|l|}
2017 \\
\end{tabular} & 2,80 (Ślaskie) & 87,20 (Warmińsko-mazurskie) & 21 & 27,19 & 90,27 \\
\hline \multirow[t]{2}{*}{$\mathrm{X} 21$} & 2010 & 0,05 (Podlaskie) & 1,08 (Ślaskie) & 0,1 & 0,23 & 103,94 \\
\hline & 2017 & 0,03 (Podlaskie) & 0,7 (Śląskie) & 0,06 & 0,13 & 118,81 \\
\hline \multirow[t]{2}{*}{$\mathrm{X} 22$} & 2010 & 0,17 (Opolskie) & 4,30 (Zachodniopomorskie) & 1,88 & 1,10 & 94,99 \\
\hline & \begin{tabular}{|c|}
2017 \\
\end{tabular} & 0,21 (Opolskie) & 7,64 (Warmińsko-mazurskie) & 4,55 & 1,96 & 126,89 \\
\hline \multirow{2}{*}{$\mathrm{X} 23$} & 2010 & 0,38 (Lódzkie) & 6,76 (Zachodniopomorskie) & 4,41 & 2,25 & 77,09 \\
\hline & 2017 & 0,44 (Opolskie) & 8,57 (Warmińsko-mazurskie) & 6,99 & 2,82 & 95,92 \\
\hline \multirow{2}{*}{$\mathrm{X} 24$} & 2010 & 54,00 (Opolskie) & 330,00 (Mazowieckie) & 70 & 139,00 & 52,67 \\
\hline & 2017 & 49,00 (Opolskie) & 272,00 (Małopolskie) & 66 & 139,63 & 47,19 \\
\hline
\end{tabular}

Source: own study based on local bank data, available at https:// bdl.stat.gov.pl/BDL/start (retrieved 16.06.2019)

Another area considered significant in determining economic development is economic activity of households, which was characterized using five different indicators (Table 1).

Coefficient of variation for the economic activity rate (X25), calculated as a percentage of the economically active population of a given category in the total population of a given category, indicates a small disparity in the different Polish regions. A high level of employment is fundamental to social and economic cohesion. Employment policy should be aimed at creating more jobs, encouraging people to take up employment, improving the adaptability of employees and enterprises, and increasing investment in human capital. Human capital is one of the pivotal resources conditioning the 
development of the economy as a whole. Low economic activity combined with unfavorable demographic changes (e.g. a decrease in birth rate or low fertility rate) may pose a threat to servicing the pension system in the future. For Lubuskie region, the lowest rate was reported for university graduates per 10,000 population (X26), which is not conducive to the economic development of the region due to the potential lack of human resources. Providing human resources for science and technology is the basis for increasing the innovative capacity of a knowledge-based economy. In the case of Lubuskie, this may be due to the fact that there is no academic tradition in the region, while the operating centers have a relatively short history. It is worth noting that this variable showed the most fluctuations across Polish regions. Alarmingly, the disparity between the individual regions only increased in 2017 compared to 2010. The growing indicator of the average monthly disposable income per capita in households (Poland 100) (X27) indicates greater consumer opportunities, and indirectly also an improved quality of life. An increase in this indicator results in the growing diversification of the structure of household expenditures, which is linked with better well-being. Households with low incomes are forced to give up not only meeting higher-order needs (such as education, culture, leisure), but often even basic life needs. Low disposable incomes and wide disparities between regions may lead to marginalization of a part of society, which is why the down ward volatility of this variable in 2017 compared to 2010 is of significance. Lubuskie region remains in this context slightly above Poland's average, and positive trends were observed in shaping this indicator (Table 6).

Tabela 6. Descriptive characteristics of variables explaining the area economic activity of households as an important determinant of economic development for Polish regions in 2010 and 2017

\begin{tabular}{|c|c|c|c|c|c|c|}
\hline \multirow{2}{*}{$\begin{array}{l}\text { Variables } \\
\text { reflecting } \\
\text { economic } \\
\text { activity of } \\
\text { households }\end{array}$} & \multirow[b]{2}{*}{ Year } & \multicolumn{5}{|c|}{ Descriptive statistics } \\
\hline & & Min & Max & Lubuskie & Mean & $\begin{array}{c}\text { Coefficient } \\
\text { of } \\
\text { variation }\end{array}$ \\
\hline \multirow[t]{2}{*}{$\mathrm{X} 25$} & 2010 & 52,40 (Zachodniopomorskie) & 58,00 (Mazowieckie) & 55,8 & 55,11 & 3,42 \\
\hline & 2017 & 53,10 (Śląskie) & 59,50 (Mazowieckie) & 55,3 & 55,79 & 3,23 \\
\hline \multirow[t]{2}{*}{$\mathrm{X} 26$} & 2010 & 73,00 (Lubuskie) & 153,00 (Mazowieckie) & 73 & 116,88 & 18,41 \\
\hline & 2017 & 39,00 (Lubuskie) & 158,00 (Małopolskie) & 39 & 91,44 & 31,50 \\
\hline \multirow[t]{2}{*}{$\mathrm{X} 27$} & 2010 & 76,10 (Podkarpackie) & 134,30 (Mazowieckie) & 96,7 & 96,40 & 13,00 \\
\hline & 2017 & 78,90 (Podkarpackie & 119,60 (Mazowieckie) & 99,6 & 97,46 & 9,06 \\
\hline \multirow[t]{2}{*}{$\mathrm{X} 28$} & 2010 & 22,20 (Warmińsko-mazurskie) & 27,60 (Mazowieckie) & 24,8 & 25,01 & 5,76 \\
\hline & 2017 & 24,60 (Warmińsko-mazurskie) & 30,30 (Mazowieckie) & 27,0 & 27,48 & 5,76 \\
\hline \multirow{2}{*}{$\mathrm{X} 29$} & 2010 & 9,20 (Wielkopolskie) & 20,00 (Warmińsko-mazurskie) & 15,5 & 13,64 & 22,51 \\
\hline & 2017 & 3,70 (Wielkopolskie) & 11,70 (Warmińsko-mazurskie) & 6,5 & 7,32 & 29,65 \\
\hline
\end{tabular}

Source: own study based on local bank data, available at https:// bdl.stat.gov.pl/BDL/start (retrieved 16.06.2019)

\section{Conclusion}

Poland is one of the largest beneficiaries of cohesion policy, aimed at bridging the disparities in the development of regions (Kusideł 2013; Kasztelan 2013; Kosmalski 2016). However, the county has not yet reached the level of development that would enable effective implementation of the principles of sustainable development. 
Agricultural performance in Poland is still below the EU average, while boosting the economic performance of agriculture in Poland is not recommended due to the negative social effects it entails (Matysiak and Struś 2015). Unsatisfactory results of activity are also observed in other areas. From a practical point of view, any economic activity that limits the energy and material consumption of industry and raw materials processing is also important, facilitating optimal spatial management, capped development of communication infrastructure and reduction of industrial risks. The analysis of the indicators reveals significant disproportions in the level of economic development of the Polish regions in the discussed are a reflecting economic development in the context of the progress in the implementation of the concept of sustainable development. Such disparities are observed both in terms of time and space, and they are very often a byproduct of economic, spatial and social differences related to the specificity of individual regions. Uneven development of individual regions is a natural phenomenon occurring in every country. The conducted research shows that Poland still reports significant disproportions in regional development. The regions of Mazowieckie, Dolnośląskie and Śląskie are clear leaders, and an overall trend can be noticed that regions with a competitive and innovative economy are those with the largest and most dynamically developing agglomerations, which are the main source of growth and employment. Lubuskie region, due to its limited exploitative potential arising from: limited natural resources, low population and small surface area, lack of large agglomerations and the fact it only recently became an independent administrative unit, requires numerous activities to be undertaken in order to boost the region's potential. Having said that, it should be noted that in 2017, compared to 2010, improvement was reported in many indicators characterizing Lubuskie region, allowing the region to increasingly mark its presence on the map of Poland.

\section{Acknowledgment}

This research was supported by the Board of Lubuskie Provinceas part of the initiative "Small Grants for Public Universities".

\section{References}

Bal-Domańska, B. (2016). Pomiar zrównoważonego rozwoju na poziomie lokalnym i regionalnym na przykładzie Banku Danych Lokalnych. Optimum. Studia Ekonomiczne, nr 1(79).

Borys, T. (2003). Wskaźniki zrównoważonego rozwoju - badania i implementacja. In: Zarzqdzanie zrównowaz̧onym rozwojem, T. Borys (ed.). Białystok: Wydawnictwo Ekonomia i Środowisko.

Borys, T. (2011). Zrównoważony rozwój - jak rozpoznać ład zintegrowany. Problemy ekorožwoju, 6(2), 75-81.

Brutland, G.H. (1987). Report of the World Commission on Environment and Development. z: available on http://www.un.org/documents/ga/res/42/ares42-187.htm, date of access: 15.05.2019.

Cieślak, I., Pawlewicz, K., \& Pawlewicz, A. (2019). Sustainable Development in Polish Regions: a Shift-Share Analysis. Polish Journal of Environmental Studies, 28(2), 565-575.

Jędrzejczak-Gas, J. Barska, A., (2019). Assessment of the Economic Development of Polish Regions in the Context of the Implementation of the Concept of Sustainable Development - Taxonomic Analysis. European Journal of Sustainable Development, 8(5), 222-233

Jovovic, R., Draskovic, M., Delibasic, M., \& Jovovic, M. (2017). The concept of sustainable regional development - institutional aspects, policies and prospects. Journal of International Studies, 10(1), 255-26. 
Kasztelan, A. (2013). Regional development based on environmental competitive advantages-a comparative analysis of Polish voivodships. Comparative Economic Research, 16(2), 105-122.

Kisiała, W. (2016). Nierówności regionalne a wzrost gospodarczy — weryfikacja hipotezy odwróconego U Williamsona. Prace Naukowe Uniwersytetu Ekonomicznego we Wroctawiu, 439, 167-177.

Kosmalski, R. (2016). Konwergencja gospodarcza w Polsce w ujęciu sektorowym. Wiadomości Statystycz̨ne, 61(2), 47-61.

Laurencio Calas, P., \& Fuentes Sardinas, R. (2017). Economic fundament towards sustainable development in the Mining Region. AVANCES, 19(2), 126-133.

Leibenath, M., Korcelli-Olejniczak, E., \& Knippschild, R. (2008). Cross-border governance and sustainable spatial development. Berlin, Germany: Springer, 1039-1044.

Ladysz, I. M. (2015). Security challenges in the regional policy of the Lower Silesian Voivodship. In: Financial aspect of the challenges of regional policy in the new programming period, ed. M. Dylewski. Zesayty Naukowe Wyższej Szkoty Bankowej, Vol. 58 No. 1.

Kusideł, E. (2013). Konwergencja wojewódzkich wskaźników ładu społecznego. Folia Oeconomica, 293, 123130.

Matuszczak, A. (2013). Zróżnicowanie roz̨ooju rolnictwa w regionach Unii Europejskiej w aspekcie jego zrónnoważenia. Wydawnictwo Naukowe PWN: Warszawa.

Matysiak, A., \& Struś, M. (2015). Paradygmat rozwoju zrównoważonego. Studia Ekonomicznne, (213), 11-21.

Pająk, K., Dahlke, P., \& Kvilinskyi, O. (2016). Determinanty rozwoju regionalnego -współczesne odniesienie. Roczniki Ekonomiczne Kujawsko-Pomorskiej Szkoly Wy ższej w Bydgoszçy, (9), 109-122.

Poczta-Wajda, A., \& Sapa, A. (2017). Paradygmat rozwoju zrównoważonego - ujęcie krytyczne. Progress in Economic Sciences, (4).

Raszkowski, A., \& Bartniczak, B. (2018). Towards sustainable regional development: economy, society, environment, good governance based on the example of Polish regions. Transform. Bus. Econ, 17, 225-245.

Roszkowska, E., \& Filipowicz-Chomko, M. (2016). Analiza wskaźnikowa zróżnicowania rozwoju społecznego województw Polski w latach 2005-2013 w kontekście realizacji koncepcji zrównoważonego rozwoju. Ekonomia i Środowisko, nr 1, 76-97.

Roszkowska, E., \& Filipowicz-Chomko, M. (2016). Ocena realizacji koncepcji zrównoważonego rozwoju województw Polski w zakresie poziomu rozwoju społecznego w roku 2005 oraz 2013. Optimum. Studia Ekonomiczne, nr 3(81), 94-118.

Skowroński, A. (2006). Zrównoważony rozwój perspektywą dalszego postępu cywilizacyjnego. Problemy Ekorozwoju, 1(2), 47-57.

Wskaźniki zrównoważonego rozwoju Polski. (2011). Urząd Statystyczny w Katowicach, Katowice.

Wyrwa., J. (2014). Smart specialisation - a novel approach towards region development in Poland. Acta Scientiarum Polonorum. Oeconomia, 13(3), 143-154.

Ulfik, A., \& Nowak, S. (2014). Determinants of Municipal Waste Management in Sustainable Development of Regions in Poland. Polish Journal of Environmental Studies, 23(3). 